\title{
E-COMMERCE IN TRADE COMPANIES DURING THE CONDITIONS OF A PANDEMIC CRISIS - CASE STUDIES
}

\author{
Sandra Mrvica Mađarac, PhD, College professor \\ College of Applied Sciences "Lavoslav Ružička" in Vukovar \\ Županijska 50, Vukovar, Croatia \\ smrvica@vevu.hr
}

\section{Zvonimir Filipović, MSc in Economics, Lecturer}

PIK Vrbovec plus d.o.o.

Gospodarska zona 20, Antunovac, Croatia

zvonimir88@gmail.com

\author{
Marko Eljuga, MSc in Economics, Lecturer \\ Agro - Honor d.o.o. \\ Vrbaska 1c, Osijek, Croatia \\ marko.eljuga@gmail.com
}

\section{ABSTRACT}

E-commerce in trade companies during the course of the pandemic crisis has become more than a technology; it includes a whole range of activities such as business processes, business organization, communication, customer relationship management, the E-sales orientation and business progress through the Information and Communication technologies. The consequences of the pandemic COVID-19 are reflected on the various spheres of social life, including the businesses of the companies. New strategies and techniques in business have positively contributed to the survival of trading companies on the market in the new situation. Therefore, trading companies were forced to adjust their way of working, doing business and maintaining contacts with the customers and suppliers in the new situation.

E-commerce in trading companies has become much more than the E-sales. Digitalising business leads to the implementation of E-commerce of the supply chain management that leads to speeding up and maintaining of the business processes. Due to rapid technological changes, E-commerce needs to follow new trends on the Information and Communication technologies market in order to remain effective. E-commerce can also help to organize communication processes. Online sales in the situation of the pandemic crisis have proven to be an effective 
sales method with which trading companies can maintain their sales in contactless customer relations. With the E-commerce can be improved all the company's business relations by the introduction of opportunities that it provides in business, by building architecture of E-commerce and by implementation of applications for business enterprises taking into account the potential costs and benefits of introducing this kind of business. However, with the introduction of E-commerce, both of the marketing strategies and the market expansions can be improved.

In the paper are listed and analysed changes in the trade operations of the two companies due to the pandemic crisis; one deals with the sale of agricultural machinery and the other with the sale of food products: at this point we examine and compares the differences in the business processes management with the customers and suppliers in the normal way of doing business also in the new occasions, that is the consequential business adjustment in the course of pandemic.

Keywords: business processes, E-commerce, online sales, the pandemic crisis, trade companies

\section{INTRODUCTION}

Accordingly, towards today's modern trends for digitization and transformation of markets, e-commerce is evolving as a business model. The implementation of ecommerce in the company consists of several stages; from the introduction of the company's Website, e-sales to the introduction of e-commerce in all organizational units of the company. In the conditions of the COVID-19 pandemic, when direct contact between employees, employees and customers, as well as employees and suppliers is hindered, the e-commerce proved to be an ideal solution.

This topic was chosen for the purpose of determining the situation on the example of the two companies on how they have adapted to the market in the emerging pandemic situation with regard to their businesses. Also, we wanted to determine whether companies have improved their e-commerce, with regard to the online work from home, therefore in a situation of reduced social contacts and in what way.

In the paper, on the example of the two trade companies, the e-commerce and the changes that occurred in the conditions of the COVID-19 pandemic have been analysed. Analysed were the implementation of e-commerce in business processes and its results. Company $\mathrm{X}$ is a food stuff production and sales company, while company $\mathrm{Y}$ specializes in retail and wholesale and service of small agricultural machines.

\section{THE MEANING OF E-COMMERCE}

E-commerce represents a complex combination of business processes, entrepreneurial operations, and organizational structures that are needed to create a highly 
efficient business model ${ }^{1}$. E-commerce can be used to: improve services and provide access to customers that exists outside the local market, to help in promotion and to help to organize business processes more efficiently in the company, enabling price comparison, also enabling market competitiveness, reduce business transaction costs, increase company visibility in the market, improved access to the company for customers and suppliers, enabled communication and doing business outside the office and facilitated the procurement of products and services ${ }^{2}$. The implementation of e-commerce can be seen as the ability of an organization to enrich technological innovation by adopting and using new business solutions for e-commerce ${ }^{3}$.

When it comes to electronic business, most people first think of e-commerce. Electronic commerce (e-commerce) means the process of buying, selling, transferring or exchanging products, information's or services by means of the Internet. E-business or electronic business is a more complex term which, in addition to buying and selling products and services, implies servicing, cooperation with the business partners and performing electronic transactions within organizations $s^{4}$. E - commerce has developed in three phases ${ }^{5}$ :

- The first stage is marked by the presence of E-commerce (1994-1997); i.e., to ensure that every business has its own Website and is present on the Internet

- The second stage characterised the business transaction phase (1997-2000); buying and selling through digital channels, and the goal was the flow of orders and gross profit

- The third stage is marked by the impact of e-commerce on the profitability of companies (from 2000 onwards); this phase is called e-commerce and includes all applications for enterprise operation and a comprehensive strategy of redefining old business models through the use of technology.

World trade is experiencing an increase in e-commerce; from 1,115,7 trillion US dollars in 2016 to 3,5 trillion US dollars in $2019^{6}$.

Kalakota, R.; Robinson, M., E-business 2.0. , Mate, Zagreb, 2002, p. 4.

2 Ministry of Entrepreneurship and Crafts, E-business for the competitiveness of your company in the modern world, Ministry of Entrepreneurship and Crafts, Zagreb, 2014., p. 12.

3 Hull, C. E. et al., Taking advantage of digital opportunities: A typology of digital entrepreneurship, International Journal of Networking and Virtual Organisations, Vol. 4, No. 3, 2007, pp. 290-303.

4 E-business - how, what, where? 2018, [www.datalab.hr] Accessed 12 February 2021.

5 Kalakota; Robinson, op. cit., note 1, p. 5.

6 Clement, J., Retail e-commerce sales growth worldwide 2017-2023., 2020, [https ://www.stati sta.com/ stati stics /28848 7/forec ast-of-globa l-b2c-e-comme rce-growt h/] Accessed 18 June 2020. 
E-commerce in today's business does not only encompasses a company's Website where the company introduces itself to the existing partners and customers, but also implies a powerful marketing tool for gaining new customers and business partners. E-commerce involves focusing on the customer and satisfaction of his needs ${ }^{7}$. The advantages and solutions provided by the application of e-commerce are related to the competitive advantage of the company. However, still missing is the empirical research that analyses the benefits of e-commerce and competitive advantage ${ }^{8}$. The use of the Internet in business has become a subject of interest to scientists and business entities. Information technology and its role in guiding the success of the company and the use of the Internet is of strategic importance to the company. Information Tecnology has transformed processes, products, enterprises and industries ${ }^{9}$. Conducted research on e-commerce ${ }^{10}$ has shown that the adoption of e-commerce depends on internal and external resources. For instance, the government support, global orientation and an effective organizational structure of the company are significant prerequisites for the introduction of e-commerce to improve the competitiveness of companies.

An important part of e-commerce, especially in commercial companies is e-marketing. E-marketing is a way of conducting marketing activities of a company with a significant application of information (Internet) technology ${ }^{11}$. E-marketing is seen as the process of building customer relationships through online activities for the purpose of exchanging ideas, products and services for them to meet the goals of the parties involved ${ }^{12}$. The marketing functions of the economic entity that are applicable through the Internet are: product development policy, policy of product and service sales, gathering information's about the market, market research, promotion and advertising and e-distribution ${ }^{13}$. Through the e-marketing, the customer participates in the activities of the company, which enables the re-

Kalakota; Robinson, op. cit., note 1, p. 6.

8 Pilinkiene, V.; Kurschus, R.J.; Auskalnyte, G., E-business as a source of competitive advantage, Economics and Management, Vol. 18, No. 1, 2013, pp. 77-85.

9 Porter, M.E.; Millar, V.E., How information gives you competitive advantage, Harvard Business Review, Vol. 63, July-August,2013, pp. 149-160.

10 Shehata, G. M.; Montash, M. A., Driving the internet and e-business technologies to generate a competitive advantage in emerging markets: Evidence from Egypt, Information Technology \& People, Vol. 33, No. 2, 2019, pp. 389-423.

11 Panian, Ž., Internet and small business, Informator, Zagreb, 2000, p. 15.

12 Mohammed, R.A., Internet marketing: Building Advantage in a Network Economy, Irwin/McGraw Hill, 2004.

13 Panian, op. cit., note 11, p. 22. 
organization of the product creation process according to the wishes of its users, which is more than it was the case in the traditional approach to marketing ${ }^{14}$.

Here are the rules of E-commerce ${ }^{15}$ :

- The technology for forming a business strategy represents its commencement and follows the guiding idea

- Impact on the flow of information and the ability to increase their efficiency provide more powerful and cost-effective services than those needed for the production and sale of material products

- The inability to move from an outdated business pattern leads to business failure

- By using e-commerce companies can become the most recognizable to customers

- Technology should be used not only to create a product but to improve the activities that surround the product

- In the future, reconfigurable e-commerce models will be used to better meet customer requirements

- The goal of the solution in e-commerce is to create flexible alliances, not only with the aim of reducing costs but also with the aim of delighting its customers

- Error that happens when creating urgent e-commerce projects when minimizing application structure needs can be costly

- The key to success is the ability to quickly plan the path taken by the ecommerce infrastructure and its construction

- A difficult task for management is how to quickly and correctly connect business strategies and processes.

In Table 1 are shown the main trends that govern e-commerce.

14 Ružić, D.; Biloš, A.; Turkalj, D., e-Marketing, Faculty of Economics in Osijek, Osijek, 2009, p. 182.

15 Kalakota; Robinson, op. cit., note 1, p. 6. 
Table 1. Main trends that govern e-commerce

\begin{tabular}{|c|c|}
\hline Trend category & Trend \\
\hline The customer & $\begin{array}{l}\text { - Faster service } \\
\text { - Self - service } \\
\text { - Larger selection of products } \\
\text { - Integrated solutions }\end{array}$ \\
\hline E-self-service & $\begin{array}{l}\text { - Integrated sales and service } \\
\text { - Smooth support } \\
\text { - Flexible fulfilment of orders } \\
\text { - Increased process visibility } \\
\end{array}$ \\
\hline Organization & $\begin{array}{l}\text { - Relocation of business to the external environment } \\
\text { - Production based on contract } \\
\text { - Virtual distribution }\end{array}$ \\
\hline Employee & $\begin{array}{l}\text { - Recruiting of the best } \\
\text { - Retaining talented employees }\end{array}$ \\
\hline Technology for business operations & $\begin{array}{l}\text { - Integrated applications needed for the business of the } \\
\text { company } \\
\text { - Integration of multiple channels } \\
\text { - Intermediary applications between old and new soft- } \\
\text { ware and hardware and machinery }\end{array}$ \\
\hline General technology & $\begin{array}{l}\text { - Wireless Web applications } \\
\text { - Mobile devices for information processing and ex- } \\
\text { change } \\
\text { - Convergence of infrastructure components } \\
\text { - Application of service providers }\end{array}$ \\
\hline
\end{tabular}

Source: Kalakota, Robinson, 2002, p. 42

The results of research on e-commerce during the COVID-19 pandemic ${ }^{16}$ indicate a positive impact of external factors on the adoption of e-commerce and e-marketing.

The relationship between small businesses, technology and industrial systems generates e-commerce competencies. Industrial, technological, and social e-commerce encounters come together to create soft skills (e.g., for the ability to learn new trends) that help small businesses to adapt to the digital marketplace ${ }^{17}$. The growth of intellectual capital has been confirmed by the great advances in Information Technology and the growth of a knowledge-based economy in which investing in

16 Patma, T. S., The Shifting of Business Activities during the COVID-19 Pandemic: Does Social Media Marketing Matter?, Journal of Asian Finance, Economics and Business, Vol. 7, No. 12, 2020, pp. 283-292.

17 Mkansi, M., E-business adoption costs and strategies for retail micro businesses, Electronic Commerce Research, Vol. 21, No. 1, 2021, pp. 1-41. 
e-commerce is crucial ${ }^{18}$. Modern companies need not only to implement e-commerce but also to create value for customers. This comprises converting resources into value and extracting profits. Businesses need to manage customer needs, produce what customers demand, and to provide product value to customers (to manage Internet commerce) ${ }^{19}$.

Enterprises dealing with the e-commerce are in good position to use social influence among customers as a tool to help in the course of decision-making by enabling the customer to claim suitability guidelines and reviews ${ }^{20}$. In a research $^{21}$ from 2021 is indicated that companies that deals with the e-commerce can through the online channels make an agreement about forming the revenues to optimize decentralized decision-making and to achieve significant cooperation between supply chain participants. When implementing e-commerce, the main problem is the structure of software components and arising of possible, potential integration shortcomings that are often overlooked through the logic of a business application. The weakest link in e-commerce applications that are based on social networks is the logical subversion of the server-side component caused by the computer developers who are involved in the software design process ${ }^{22}$. A research $^{23}$ from 2021 indicates that the supply chain of the e-commerce platforms based on Internet of Things (IoT) technology have a lower risk of loss. The application of this type of technology will effectively reduce the market risk of the supply chains financing and it will better serve to the economic development. The Covid pandemic has affected online payments and e-commerce around the world. It has been shown with the researches and with the market reports that the buyer's interference on the Internet increases during a pandemic ${ }^{24}$.

18 Al-Omoush, K. S.; Simon-Moya, V.; Sendra-Garcia, J., The impact of social capital and collaborative knowledge creation on e-business proactiveness and organizational agility in responding to the COVID-19 crisis, Journal of Innovation \& Knowledge, Vol. 5, No. 4, 2021, pp. 279-288.

19 Scarpa, P.F., AN e-business blueprint-how you measure and manage the risks of an e-business will or will not give you that competitive edge: here's a model for success, Ivey Business Journal, Vol. 64, No. 4, 2020, pp. 62-71.

20 Zong, et al., Or-based Intelligent Decision Support System for E-commerce, Journal of Theoretical and Applied Electronic Commerce Research, Vol. 16, No.4., 2021.

21 Wang, D.; Lee, W., Optimization algorithm and simulation of supply chain coordination based on cross-border E-commerce network platform Open Access, Eurasip Journal on Wireless Communications and Networking, No. 1, 2021, Article number 23.

22 Nabi, F.; Tao, X.; Yong, J., Security aspects in modern service component-oriented application logic for social e-commerce systems, Social Network Analysis and Mining, Vol. 11, No.1, Article number 22.

$23 \mathrm{Yu}, \mathrm{H}$. et al., Research on the financing income of supply chains based on an E-commerce platform, Technological Forecasting and Social Change, Vol. 169, 120820.

24 Afridi, F. E A. et al., The impact of Covid-19 on E-business practices and consumer buying behavior in a developing country, The Revista Amazonia Investiga, 2021, Vol. 10, No. 38. 


\section{RESEARCH METHODOLOGY AND HYPOTHESES}

For the purposes of this research, a primary survey of two trade companies in Osijek-Baranja County was conducted. The aforementioned research was conducted from January 10 to January 30, 2021. A qualitative research was conducted using the technique of free organized interview with encompassed of all of the management representatives from the both companies.

A research interview is an extraordinary and artificially created situation initiated by an interviewer with the aim of gathering information's relevant to some research problem, while taking into account the scientific tasks of describing, predicting and explaining of such problems ${ }^{25}$. The method of examination, which in a broader sense of the word is a method of collecting data on the subject that is researched is based on the opinion of the respondents, but in a narrower sense - it is actually a survey method, interview method, and also encompasses tests and scaling methods ${ }^{26}$. The research was conducted in a semi-structured interview manner.

The main goal of the research was to identify the use and implementation of ecommerce in the conditions of the COVID-19 pandemic in the two observed trading companies. The case method aims to connect the relationship between theory and practice, i.e., between deduction and induction. In the case method, in addition to the theoretical part, cases from practice are also presented ${ }^{27}$. The case study method deals with the study of a phenomenon as a convergence of circumstances in which there does not seem to be inflicted cause-and-effect sequence. In order to gain useful experience, it is necessary to observe not one but several other cases. In this way, tendencies can be reached in the studied phenomenon ${ }^{28}$.

In relation to the set theoretical-methodological approach and the title of the issue, it is possible to set hypotheses:

$\mathrm{H}_{1:}$ The analysed companies by implementing e-commerce have adapted to the new situation.

$\mathrm{H}_{2 .}$ Due to e-commerce, the realization of sales was maintained with good results in 2020.

25 Milas, G., Research methods in psychology and other social sciences, Jastrebarsko, Naklada Slap, 2005.

${ }_{26}$ Žugaj, M.; Dumičić, K.; Dušak, V., Foundations of scientific research work: methodology and methodology, Varaždin, Tiva, 2006. p. 114.

27 Baban, Lj. et al., Application of professional and scientific research methodology, Faculty of Economics in Osijek, Osijek, 2002, p. 144.

28 Ivanović, Z., Methodology of scientific research, Saiva, Kastav, 2011, p. 253. 


\section{E-COMMERCE OF THE COMPANY X}

Since it is a large manufacturing company which has a developed organizational structure and is a market leader in the segment of products it produces, it is understood that e-commerce is implemented in all company processes, from production stages to sales. During the time before the pandemic, certain elements of ecommerce were used, such as e-mails, B2B (business to business - business model between the two companies) and $\mathrm{B} 2 \mathrm{C}$ (business to customer - business model between the company and its customers), i.e., the platforms which were sufficient to support the classical business model, whether it was the production, acquisition or sale of the enterprise. E-commerce means P2P - the path to profitability ${ }^{29}$. Marketing is the one who listens to the needs of the market or even sometimes creates them and therefore indirectly and with the help of other services gives boost to the service development for the production of certain products that with the help of the engagement of the sales department will be offered to customers through various sales channels. In the circumstances before the pandemic of COVID-19 all departments within the company have communicated electronically, but not only and exclusively electronically. Large part of the businesses is arranged in classical meetings, face-to-face between the service area within the company or in meetings with the business partners. Usually, all meetings are accompanied by memoranda presented in electronic form and thus facilitate the uninterrupted continuation of the agreed activities at the meetings that were held. In the conditions before the pandemic, it is crucial to note that the e-commerce has been implemented in all aspects of the company's businesses, but it should once again be emphasized that it has almost always existed as a support and tool for easier business processes, and not strictly as an exclusive way of doing business. The emergence of the pandemic has brought completely new conditions, not just for companies that operates on the free market. but also, a new organization of the work itself within the company. The situation with the pandemic brought a number of restrictions in order to preserve human health, such as maintaining physical distance and limiting the gathering of the greater number of people in one place. The measures brought by the Civil Protection Headquarters introduced numerous restrictions, but not only in the unhindered movement of individuals, but they also directly limited certain economic branches, such as tourism, catering and trade. The company consequently can be compared to a living organism. A living organism needs oxygen in order to function smoothly, and also a company needs to achieve added value through the realization of its business functions, in order to be able to survive and move forward on the open market. E-commerce requires strategic business plan-

29 Berman, D., Dot-Coms: Can They Climb Back?, 2020, [https://www.bloomberg.com/news/articles/2000-06-19/dot-coms-can-they-climb-back], Accessed 12 January 2021. 
ning that takes place through specific steps ${ }^{30}$. All of these new circumstances required a quick reaction of the company's management in order for the company's business to continue in the new environment. The management made decisions related primarily to preserve the health of all employees of the company, but it has also brought decisions that ensured the continued manner of business activities that are extremely important for the wider community in which the company operates, because it is a company that produces and sells food products that are necessary for the withstand of the life of the population. The pandemic had made an impact on the transformation of business within all services in the company, as well as in mutual communication within the company and also in communication with the business partners and clients situated outside the company. Regardless of the circumstances in which the management had to make such decisions, the vision had to be taken into account as a clear idea of the nature of the future events, i.e., about the long-term desired result ${ }^{31}$.

In the production service, multiple teams with a smaller number of employees were formed, in order to reduce unnecessary mutual contacts to a minimum. Novelties have been introduced in the shift schedule, with breaks between shifts so that all appropriate working places may apply the disinfection measures and disinfection of the working tools. The communication of responsible persons within the production service was transferred from internal meetings and briefings towards the online platforms: Zoom, Skype and Microsoft Teams. Production orders also began to circulate in e-form and WhatsApp groups began to be used on the mobile phones for all of the less important communication between employees within the service that were divided by rank of responsibilities and assigned to specific teams and project tasks. The procurement service has faced very big challenges in the conditions of the COVID-19 pandemic. In the conditions of numerous restrictions both in international traffic and crossing of state borders, as well in local traffic, it was necessary to provide unobstructed supply of raw materials necessary for uninterrupted production. Many partners and suppliers of raw materials were not able to deliver raw materials on time and in the conditions before the onset of the pandemic, which posed additional challenges to the procurement service. The entire procurement process has been transferred from classic business methods to the e-commerce. The search for the new suppliers in the newly emerging pandemic situation, negotiations with existing business partners and the mutual communication of teams within the service took place via e-platforms. Business meetings and direct contacts were moved to a virtual space via indirect contact, most often through the Zoom platform, but also all other available platforms,

\footnotetext{
30 Spremić, M., Management and e-business, Narodne novine, Zagreb, 2004.

31 Čičin-Šain, D., Vision, mission and goals, University in Zadar, 2013.
} 
depending on the preferences and ways that were chosen by the business partners. Meetings via virtual communication platforms required a lot more preparation in order to achieve better communication and faster agreements in limited conditions. Employees of the service have been redeployed to work from home to ensure maximum safety for employees in terms of the health threat posed during the pandemic, for them to needlessly contaminate employees that are necessary for a smooth and continuous production process. Regardless of the work from home, all the work of the service necessary for the work of the company took place every day in the course of the normal working hours. Employees within the service were, with the help of mobile platforms and virtual meeting platforms, in daily communication. Delegation of tasks and reports on the fulfilment of set goals have also taken place through mobile e-commerce platforms. Administrative services, such as the legal service, the human resources service and the financial service are also maximally redeployed to work from home. The efficiency of the services should not be reduced in relation to the conditions set in normal circumstances. All contacts within the services take place through online platforms and mobile communication groups. The Information Technology department has done a tremendous job to ensure network security and the availability of databases of employees who are working from home. The maximum transparency of the entire organization of work in the course of a pandemic ensured that the end user of a particular service did not gain the impression that it was done in circumstances that were irregular. All requests for individual services have taken place via e-commerce platforms that are also serviced via electronic platforms. All available tools for virtual meetings and communications were used, such as Zoom, Microsoft Teams, Skype, WhatsApp and others. Of course, the classic communication done via the mobile phones and e-mails, which is supported by the new tools that were raised to a higher level of efficiency, should not be neglected. Classic business and circulation of documents in paper form was almost completely replaced by circulation of documents in electronic form, which did not affect the quality of the work performed, in fact, it has increased efficiency of certain tasks, with certain savings in time and resources that were used to perform the task.

For the sales department, which in normal business conditions is faced with a large number of challenges in order to achieve all the goals set before it by the company's management, the challenges have multiplied in the conditions of the COVID-19 pandemic. The service is structured in such a way that there are present the sales manager, key account managers, sales managers of certain areas, and the sales force that is in charge of sales execution and improvement of selling's at the exact selected locations to which they have delegated their responsibility. The employees of the sales department during the normal circumstances before 
a pandemic have used a large number of tools which can be considered as tools of e-commerce. Therefore, customer orders are processed via electronic handheld devices based on mobile platforms. A significant place in the sales process is still occupied by personal contact of buyer-seller, i.e., face-to-face contact; however, in the conditions of a pandemic such contacts were not possible. With selling at higher levels, its activities of consultation and negotiation with business partners and potential customers through the platform for virtual meetings and communication were held. Communication within sales teams has moved to the field of mobile communication groups such as WhatsApp and the others. The most restrictive measures, which caused restrictions on the movement of persons and limited the number of persons in certain sales areas, required prompt organization of mobile contact centres that communicated with customers via mobile phones and then forwarded orders for processing via existing e-platforms. All of this required maximum flexibility for sales staff and increased understanding of the circumstances in which customers operated. As the existing sales channels could not absorb the increased customer demand for their products, the need for a new sales channel appeared. Sales were formed by means of a Web store that was developed very quickly and based on existing platforms and it comprehended the most of existing logistical and human resources to deliver goods to the doorstep. All the efforts invested in organizing sales and moving sales entirely to electronic and mobile platforms have yielded very good results for the company itself and justified the enormous effort of all involved in sales processes, each at their own level of responsibility. In Table 2. are shown the sales of product A in relation to year.

Table 2. Sales of product A by year in company X

\begin{tabular}{|c|c|c|c|c|}
\hline $\mathbf{2 0 1 6 .}$ & $\mathbf{2 0 1 7 .}$ & $\mathbf{2 0 1 8 .}$ & $\mathbf{2 0 1 9}$ & $\mathbf{2 0 2 0 .}$ \\
\hline 7950000 & 8100000 & 8350000 & 8200000 & 7600000 \\
\hline
\end{tabular}

Source: Business documentation of company X, 2021.

Communication within the company has almost completely moved into the virtual space on e-commerce platforms. All services within the company have undergone an organizational change within their regular business, and some new business practices based on e-commerce have begun to operate. Large part of the novelties that have been introduced as necessary in such exceptional circumstances, proved to be good and effective, and certainly is likely to continue to be used even after the pandemic of COVID-19, in times when their introduction will show additional benefits in terms of improving the efficiency and profitability of the very business processes. Numerous procedures have been simplified and digitized and are therefore much more transparent than before. 


\section{E-COMMERCE OF COMPANY Y}

The business of company Y, which sells and services small agricultural machines, as well as the business of almost all other companies, due to the pandemic crisis of COVID 19 has undergone many changes, among which it is necessary to single out changes in digital business of the company. Due to the crisis itself, company $\mathrm{Y}$ had, like other companies with the same activity, a ban on operations by the competent institutions ${ }^{32}$. In such situation, all the forces of the business were focused on e-commerce. Since company Y has previously attached a lot of importance to e-commerce (by which it is meant that the company already has had developed its own Website, Facebook page and that these pages have been in circulation for a long time), not much was needed to be done for the e-commerce to prosper as well as possible.

At the very beginning of the development of e-commerce, company $\mathrm{Y}$ was based on its own created Website where it offered its products and services. Of course, at the very beginning, this was done simply without detailed business processes and thus digital business did not have a major impact on achieving of the sales results. As the time went on, company Y refined its Website several times, where day by day it published more and more information about the products from its range and the services it deals with. Consequently, the traffic on the site was higher and, of course, the higher was the business realization through e-commerce. During 2015, the company also opened a Facebook page where it occasionally publishes novelties in its range, but also other things that are of interest to potential customers. E- commerce requires a lot of effort and time to put all the products and spare parts that company Y has in stock on the Website, but since the company has recognized the potential of e-sales, it was decided to attach a great importance to it.

Additional employees were hired, who were tasked with photographing of all of the devices and spare parts owned by the company so that they too could be included in the offer on the Web. It was a great job for the company, but in the end, it paid off for the company, because a large number of customers from the Internet has an insight into the products that the company offered, and the realization itself was on the rise. Since all this had already been developed, due to the onset of the COVID - 19 pandemic crisis, it was not a problem for the company to adapt and even more - to base itself additionally towards the e-commerce. Of course, as the business enterprise was closed for customers who wanted to buy in the com-

32 Civil Protection Headquarters of the Republic of Croatia , 2020, [https://www.iusinfo.hr/aktualno/u-sredistu/41376\#o\%C5\%BEujak2020], Decision on the Civil Protection Headquarters of the Republic of Croatia, Accessed 15 February 2021. 
panies' shops, dealing with the customers was quick and they have sent their own inquiries and, therefore the customer's orders have been sent via the Internet.

The attention of a large number of potential customers has shifted to digital media (such as Internet, computers, mobile devices). We are witnessing a time when more and more people are using these media, so the Company Y has decided to dedicate itself to this segment, especially during the course of the crisis. The reason why the company $Y$ has focused more attention on digital business is certainly due to the number of people who are using Internet. Of course, during the closure of the company's stores, this was the basic and, in addition to telephone inquiries, the only option for the company's business.

The company realized that the more present it is on the Internet, the greater the chance that more people will think of it and want to do business with it.

Since in the year of 2020 the company had fewer costs when related to traditional business and marketing (by which is comprehended companies' expositions at trade shows, publishment of the magazines and the like), more resources and time have been spent in a development of e-commerce and e-marketing. The company has paid special attention to adapting its Website to mobile phones users (the number of customers that uses mobile phones is constantly on the rise) and posting new video content on its Website (Web, Facebook, Instagram). Company has regularly held Web seminars with its partners where they presented novelties, as well as how to handle the devices from the company's programme.

A large number of discounts were published by the company on its Website and this brought extremely good realization despite the crisis. Company Y managed to make some small increase in business realisation, but the most important thing was to save all the jobs. The question is what would 2020 be like for business if there has not been the COVID-19 pandemic. In Table 3. are shown the sales of product B by year.

Table 3. Sales of product B by year in company $\mathrm{Y}$

\begin{tabular}{|c|c|c|c|c|}
\hline $\mathbf{2 0 1 6 .}$ & $\mathbf{2 0 1 7 .}$ & $\mathbf{2 0 1 8}$ & $\mathbf{2 0 1 9}$ & $\mathbf{2 0 2 0 .}$ \\
\hline 166 & 179 & 228 & 248 & 279 \\
\hline
\end{tabular}

Source: Business documentation of the company Y, 2021.

What can be established with certainty is that the company, despite the COVID-19 pandemic due to its focus on e-commerce, has not reduced its sales when compared to previous years. 


\section{RESEARCH RESULTS}

The changes in the newly emerging pandemic situation related to e-commerce in company $\mathrm{X}$ are related to the implementation of e-commerce in all aspects of business. Prior to the onset of the pandemic, e-commerce as such has facilitated business operations, but it was not an exclusive business tool leading to a new organization of work within the enterprise. Company X's purchasing business has been completely transferred from the classic business trade to the e-business and all communication within the company takes place through the online platforms and mobile communication groups. The classic management of enterprise administration has been almost completely replaced by the circulation of documents in electronic form.

Changes in business during a pandemic situation in company $\mathrm{Y}$ are related to changes in the business organization. Prior to the pandemic, company $Y$ had its own Website and Facebook profile and it formerly managed trading online but in the time of the onset of the pandemic, it has increased its Internet sales and emarketing, which ultimately resulted in good business results.

By analysis of e-commerce and organization of these business processes in both observed companies in the course of the COVID-19 pandemic, $\mathrm{H}_{1}$ hypotheses has been confirmed. When taking into account the case study of both companies, it was confirmed that with the implementation of e-commerce, companies have adapted to the new situation during pandemic conditions. By analysis of sales results of the two traditional products in both companies in the course of the observed years, the $\mathrm{H}_{2}$. hypothesis was confirmed. Because of the implementations of e-commerce, sales outcomes have maintained good results in 2020. Hypotheses have been confirmed by empirical, scientific methods, methods of analysis, and also by way of synthesis and comparison.

\section{CONCLUSION}

When we attempt to compare business in the conditions before the COVID-19 pandemic and business during the course of the pandemic, we can see many similarities, but also big differences in business. When doing business during a pandemic, the companies have moved larger part of the working activities from all of the services from the company's business offices to manage work from home. The distribution of information's which monitors the business processes of the company has been further accelerated thanks to the maximum use of e-commerce platforms and tools. The unhampering running of the business process itself required the engagement of a lot more of intellectual resources from all the levels 
of employees - from top management to the production workers. The pandemic introduced great uncertainty into the business and required the adjustment of the business to the new conditions almost overnight. As a result, it did lead to the improvements of some business process and that, in fact, it brought the e-commerce to promotes the leading way of doing business of the enterprise with all its benefits that it brings, both in normal times and in limited business conditions, due to imposed numerous or restrictive measures for the protection of public health. The analysis of e-commerce and organization of business processes in both of the observed companies in the time of COVID-19 pandemic has confirmed the $\mathrm{H}_{1}$ i.e., analysed companies by implementing the e-business have adapted to the new situation. The analysis of sales results of two traditional products in both companies during the observed years confirmed $\mathrm{H}_{2}$ i.e., due to e-business, the realization of sales was maintained with good results in the year of 2020 .

The sales results indicate that both companies achieved good sales results thanks to the rapid adaptation to the new situation and the use of e-business in the sales processes.

In the company $\mathrm{Y}$ has now been realised that e-commerce has got even greater potential and that it should be constantly improved. Unlike before when e-orders were processed only when there was time to do, now the company has an employee who deals exclusively with the orders and customer issues from the Internet. And in the future the e-commerce will have the very important role in business and will continuously work on improving and monitoring of e-technology in both of the observed companies. The differences in e-commerce between the companies $\mathrm{X}$ and $\mathrm{Y}$ relate to the use of e-business in business processes; the company $\mathrm{X}$ uses $\mathrm{e}$ - business in all business processes, while company Y uses e - sales and e - marketing, while in other business processes it has not yet implemented the $\mathrm{e}-$ business forms so far.

The limitations encountered during research were such that some results from the use of e-commerce in the observed companies has become quantitatively immeasurable, because it was dealt about improving and changing organizational business processes. Suggestions for further research may be a case study for the other companies who deals with the same sales range or companies selling other products, such as clothing and footwear (including the assumption that their sales have declined), or sales of furniture and household products (including the assumption that their sales have increased). 


\section{REFERENCES}

\section{BOOK AND ARTICLES}

1. Afridi, F. E A. et al., The impact of Covid-19 on E-business practices and consumer buying behavior in a developing country, The Revista Amazonia Investiga, 2021, Vol. 10, No. 38, pp. 97-112

2. Al-Omoush, K. S.; Simon-Moya, V.; Sendra-Garcia, J., The impact of social capital and collaborative knowledge creation on e-business proactiveness and organizational agility in responding to the COVID-19 crisis, Journal of Innovation \& Knowledge, Vol. 5, No. 4, 2021, pp. 279-288

3. Baban, Lj. et al., Application of professional and scientific research methodology, Faculty of Economics in Osijek, Osijek, 2002

4. Čičin-Šain, D., Vision, mission and goals, University in Zadar, 2013

5. Hull C. E. et al., Taking advantage of digital opportunities: A typology of digital entrepreneurship, International Journal of Networking and Virtual Organisations, Vol. 4, No. 3, 2007, pp. 290-303

6. Ivanović, Z., Methodology of scientific research, Saiva, Kastav, 2011

7. Kalakota, R.; Robinson, M., E-businese 2.0., Mate, Zagreb, 2002

8. Milas, G., Research methods in psychology and other social sciences, Jastrebarsko, Naklada Slap, 2005

9. Ministry of Entrepreneurship and Crafts, E-business for the competitiveness of your company in the modern world, Ministry of Entrepreneurship and Crafts, Zagreb, 2014

10. Mkansi, M., E-business adoption costs and strategies for retail micro businesses, Electronic Commerce Research, Vol. 21, No. 1, 2021, pp. 1-41

11. Mohammed, R. A., Internet marketing: Building Advantage in a Network Economy, Irwin/ McGraw Hill, 2004

12. Nabi, F.; Tao, X.; Yong, J., Security aspects in modern service component-oriented application logic for social e-commerce systems, Social Network Analysis and Mining, Vol. 11, No.1, Article number 22

13. Panian, Ž., Internet and small business, Informator, Zagreb, 2000

14. Patma, T. S., The Shifting of Business Activities during the COVID-19 Pandemic: Does Social Media Marketing Matter?, Journal of Asian Finance, Economics and Business, Vol. 7, No. 12, 2020, pp. 283-292

15. Pilinkiene, V.; Kurschus, R.J.; Auskalnyte, G., E-business as a source of competitive advantage, Economics and Management, Vol. 18, No. 1, 2013, pp. 77-85

16. Porter, M.E.; Millar, V.E., How information gives you competitive advantage, Harvard Business Review, Vol. 63, July-August,2013, pp. 149-160

17. Ružić, D.; Biloš, A.; Turkalj, D., e-Marketing, Faculty of Economics in Osijek, Osijek, 2009

18. Scarpa, P.F., AN e-business blueprint-how you measure and manage the risks of an e-business will or will not give you that competitive edge: here's a model for success, Ivey Business Journal, Vol. 64, No. 4, 2020, pp. 62-71 
19. Shehata, G. M.; Montash, M. A., Driving the internet and e-business technologies to generate a competitive advantage in emerging markets: Evidence from Egypt, Information Technology \& People, Vol. 33, No. 2, 2019, pp. 389-423

20. Spremić, M., Management and e-business, Narodne novine, Zagreb, 2004

21. Wang, D.; Lee, W., Optimization algorithm and simulation of supply chain coordination based on cross-border E-commerce network platform Open Access, Eurasip Journal on Wireless Communications and Networking, No. 1, 2021, Article number 23

22. Yu, H. et al., Research on the financing income of supply chains based on an E-commerce platform, Technological Forecasting and Social Change, Vol. 169, 120820

23. Žugaj, M.; Dumičić, K.; Dušak, V., Foundations of scientific research work: methodology and methodology, Varaždin, Tiva, 2006

\section{WEBSITE REFERENCES}

1. Berman, D., Dot-Coms: Can They Climb Back?, 2020, [https://www.bloomberg.com/news/ articles/2000-06-19/dot-coms-can-they-climb-back], Accessed 12 January 2021

2. Civil Protection Headquarters of the Republic of Croatia, 2020, [https://www.iusinfo.hr/ aktualno/u-sredistu/41376\#o\%C5\%BEujak2020], Decision on the Civil Protection Headquarters of the Republic of Croatia, Accessed 15 February 2021

3. Clement, J., Retail e-commerce sales growth worldwide 2017-2023., 2020, [https ://www. stati sta.com/stati stics /28848 7/forec ast-of-globa l-b2c-e-comme rce-growt h/] Accessed 18 June 2020

4. E- business - how, what, where? 2018, [www.datalab.hr] Accessed 12 February 2021 